Article

\title{
Facile One-Pot Immobilization of a Novel Thermostable Carboxylesterase from Geobacillus uzenensis for Continuous Pesticide Degradation in a Packed-Bed Column Reactor
}

\author{
Xiaohui Yang ${ }^{1}$, Xudong Tang ${ }^{1}$, Fengying Dong ${ }^{1}$, Lin Lin ${ }^{2,3}$, Wei Wei ${ }^{1, *}$ and Dongzhi Wei ${ }^{1}$ \\ 1 State Key Laboratory of Bioreactor Engineering, Newworld Institute of Biotechnology, East China University \\ of Science and Technology, Shanghai 200237, China; yangxiaohui0130@163.com (X.Y.); \\ tangxudong96@163.com (X.T.); fengyingdong16@163.com (F.D.); dzhwei@ecust.edu.cn (D.W.) \\ 2 Shanghai Key Laboratory of Molecular Imaging, Shanghai University of Medicine and Health Sciences, \\ Shanghai 201318, China; linlin21023@163.com \\ 3 Research Laboratory for Functional Nanomaterial, National Engineering Research Center for \\ Nanotechnology, Shanghai 200241, China \\ * Correspondence: weiwei@ecust.edu.cn; Tel./Fax: +86-21-64251803
}

Received: 27 March 2020; Accepted: 28 April 2020; Published: 7 May 2020

\begin{abstract}
The novel carboxylesterase gene (est 741 ) was cloned from Geobacillus uzenensis. The optimal $\mathrm{pH}$ and temperature of Est 741 were 8.0 and $50{ }^{\circ} \mathrm{C}$. Through site-directed mutation, the optimum temperature of the mutant $\mathrm{M} 160 \mathrm{~K}\left(\mathrm{Est}_{\mathrm{M} 160 \mathrm{~K}}\right.$ ) was increased from 50 to $60^{\circ} \mathrm{C}$, and showed enhanced $\mathrm{T}_{1 / 2}$ of $2.5 \mathrm{~h}$ at $70^{\circ} \mathrm{C}$ in comparison to the wild type $(1.3 \mathrm{~h})$. Est $\mathrm{M}_{\mathrm{M} 60 \mathrm{~K}}$ was successfully expressed Pichia pastoris and Est $\mathrm{M}_{\mathrm{M} 160 \mathrm{~K}}$ fermentation broth was directly immobilized on epoxy-functionalized supports via a one-pot strategy to obtain the immobilized enzyme lx-Est ${ }_{\mathrm{M} 160 \mathrm{~K}}$. Additionally, $1 \mathrm{x}$-Est ${ }_{\mathrm{M} 160 \mathrm{~K}}$ showed enhanced $\mathrm{T}_{1 / 2}$ of $36.8 \mathrm{~h}$ at $70{ }^{\circ} \mathrm{C}$ in comparison to free enzyme. $1 \mathrm{x}$-Est $\mathrm{M}_{\mathrm{M} 160 \mathrm{~K}}$ could degrade various pyrethroid pesticides. After $40 \mathrm{~min}$ reaction with $50 \mathrm{U}$ of the $1 \mathrm{x}$-Est $\mathrm{M}_{\mathrm{M} 160 \mathrm{~K}}$, the malathion removal was $95.8 \%$ with a malathion concentration of $20 \mathrm{mg} / \mathrm{L}$. When $2.5 \mathrm{~g}$ lx-Est ${ }_{\mathrm{M} 160 \mathrm{~K}}$ was added to the $10 \mathrm{~mL}$ column reactor with the concentration of bifenthrin was $500 \mathrm{mg} / \mathrm{L}$ and the transfer rate of the pump was $0.7 \mathrm{~mL} / \mathrm{min}$, the degradation rate of $1 \mathrm{x}-\mathrm{Est}_{\mathrm{M} 160 \mathrm{~K}}$ to bifenthrin was $90.4 \%$. lx-Est $_{\mathrm{M} 160 \mathrm{~K}}$ exhibited high operational stability and maintained $72 \%$ initial activity after ten batches of continuous reaction for bifenthrin pesticide biodegradation.
\end{abstract}

Keywords: Geobacillus uzenensis; carboxylesterase; site-directed mutation; immobilization; pesticides biodegradation

\section{Introduction}

To a large extent, pesticide pollution has a direct impact on land and water and an indirect impact on the entire ecosystem including food safety. Microorganisms and enzymes are effective methods for biodegrading pesticides [1-3]. An important industrial enzyme, microbial-derived carboxylesterase (EC 3.1.1.1) can catalyze the hydrolysis of carboxylic acid esters, it does not require coenzymes and is resistant to organic solvents [4]. The detoxification function of carboxylesterase is attributed to the hydrolysis of the ester bonds of pesticides, thereby destroying their toxicity [5]. Whether carboxylesterase catalyzes the ester bond hydrolysis of insecticides is dependent on the structure surrounding its active site and that flanking the insecticide ester bond. Pyrethroid pesticides and some organophosphorus pesticides contain carboxylate bonds, and can be hydrolyzed by carboxylesterases to form non-toxic carboxylates and alcohols [6]. 
So far, there is no report on the Geobacillus uzenensis carboxylesterase. Because wild bacteria require specific growth conditions and are not suitable for large-scale industrial production, their recombinant enzymes are more extensively used [7]. Escherichia coli and Pichia pastoris are the most commonly used expression systems. To avoid a series of complex purification steps and inclusion body formation in E. coli, and to facilitate subsequent enzyme immobilization, Pichia pastoris with the potent alcohol oxidase (AOX) promoter was used for expression. Moreover, P. pastoris can be applied in food and pharmaceutical industries [3,8]. Protein engineering is an effective way to design and reconstruct an enzyme. Directed evolution is the most important technological strategies. Thermostability is an important enzymatic property required for most enzymes, as increased reaction temperatures would speed up the rates of enzyme-catalyzed reactions or enhance substrate solubility, promoting the transesterification reaction $[9,10]$. The thermal stability of esterase can be improved in a variety of ways, such as introducing additional hydrogen bonding, disulfide bridges, hydrophobic interactions, ion pairing, etc. [11,12]. Site-directed mutagenesis (SDM) can achieve these goals. Anchoring the enzyme to a suitable carrier is one of the most critical steps in the successful application of the biocatalyst. Epoxy resin materials are widely used for the immobilization of enzymes because the epoxy group can easily form covalent bonds with amino or thiol groups of the enzyme under mild conditions [13]. Moreover, epoxy materials are very stable at near neutral $\mathrm{pH}$ values, which makes epoxy-containing supports suitable for long storage periods $[14,15]$. Another important advantage of the resin catalysts in this study is suitable to continuously degradation pesticide. There have been studies using epoxy resin to fix cells and testing lab scale packed-bed reactors for the treatment of malathion [16]. During this process, the catalyst can be reused, thereby reducing the cost of the application. Packed-bed reactor is a practical reactor, showing high conversion efficiency and long reaction time [16,17]. It has been studied to produce lipase from Burkholderia cepacia and use it to catalyze the synthesis of biodiesel in packed-bed reactor [17]. Studies have also evaluated the performance of malathion degradation in a packed-bed reactor packed with bacteria under optimal operating conditions [18]. A major advantage of a packed bed reactor (PBR) in immobilized $\mathrm{Est}_{\mathrm{M} 160 \mathrm{~K}}$-catalyzed reaction is that the enzyme loss can be reduced by the absence of collisions between enzyme particles and an impeller when compared to a stirred tank reactor. To date, no packed-bed reactor researches has been conducted for the degradation of bifenthrin pesticides.

This study focused on a novel carboxylesterase for pesticide degradation and pesticide wastewater treatment. First, a novel carboxylesterase gene, $e^{2} t_{741}$ from Geobacillus uzenensis was successfully expressed P. pastoris. The enzymes expressed in P. pastoris are completely released into the medium and can be directly fixed on the resin via one-pot method. Further, thermal stability was increased using site-directed mutagenesis and immobilization. The stability of the operation was also improved by fixing the enzyme on an epoxy resin. After screening for the degradation of malathion and three pyrethroid pesticides, the designed packed-bed column reactor was used to treat the wastewater for better degradation of bifenthrin pesticides, and the degradation reaction was optimized. The use of immobilized carboxylesterase to degrade pesticides is cost-effective, environmentally friendly, and easy to scale up. In addition, preliminary studies on the use of epoxy resin immobilized enzymes to treat pesticide contaminated wastewater have revealed the potential industrial applications.

\section{Results and Discussion}

\subsection{Fermentation of Wild Strain}

Bacteria showing significantly hydrolyzed zones were isolated from tributyrin agar plates (Figure 1a) and identified by $16 \mathrm{~S}$ rRNA sequence analysis. After fermentation with Luria-Bertani liquid medium supplemented with olive oil as the carbon source, the growth curve and enzyme activity of the strain were recorded as shown in Figure 1b. Results showed that the bacteria were able to secrete carboxylesterase to utilize the olive oil in the culture medium (culture conditions were $50^{\circ} \mathrm{C}$ ). 

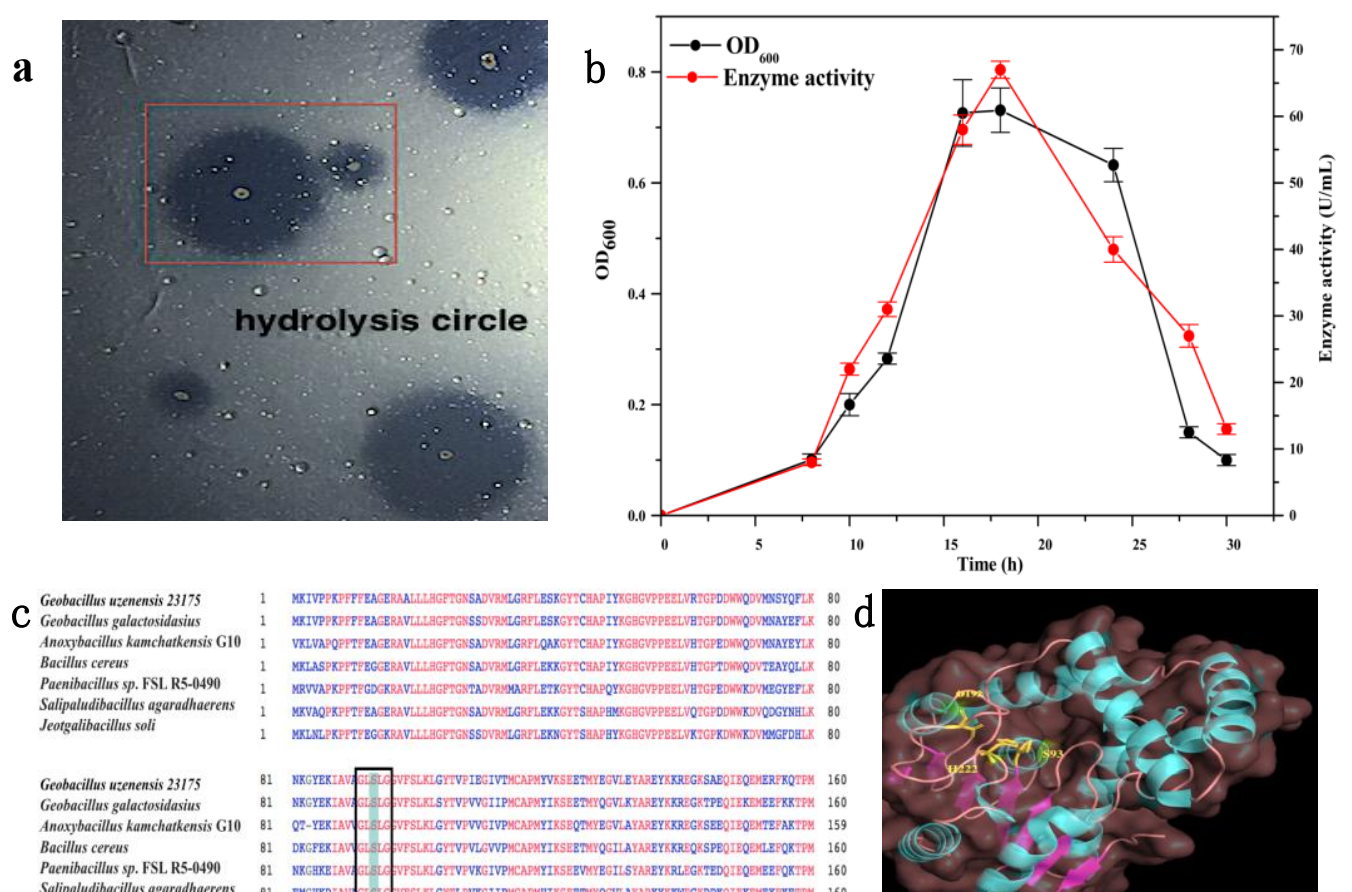
Paenibacillus sp. FSL R5-0490
Salipaludibacillus agaradhaeren Salipaludibacillus agaradha
Jeotgalibacillus soli

Geobacillus uzenensis 23175 Geobacillus galactosidasius Anaxybacillus
Bacillus cereus Paenibacillus sp. FSL R5-0490 Salipaludibacillus agaradhaerens Jeatgalibacillus soli

Geobacillus uzenensis 23175 Geobacillus galactosidasius Anoxybacillus kamchatkensis
Bacillus cereus Puemibacillus sp. FSL R5-04090 Salipaludibacillus ag
Jeotgalibacillus soli

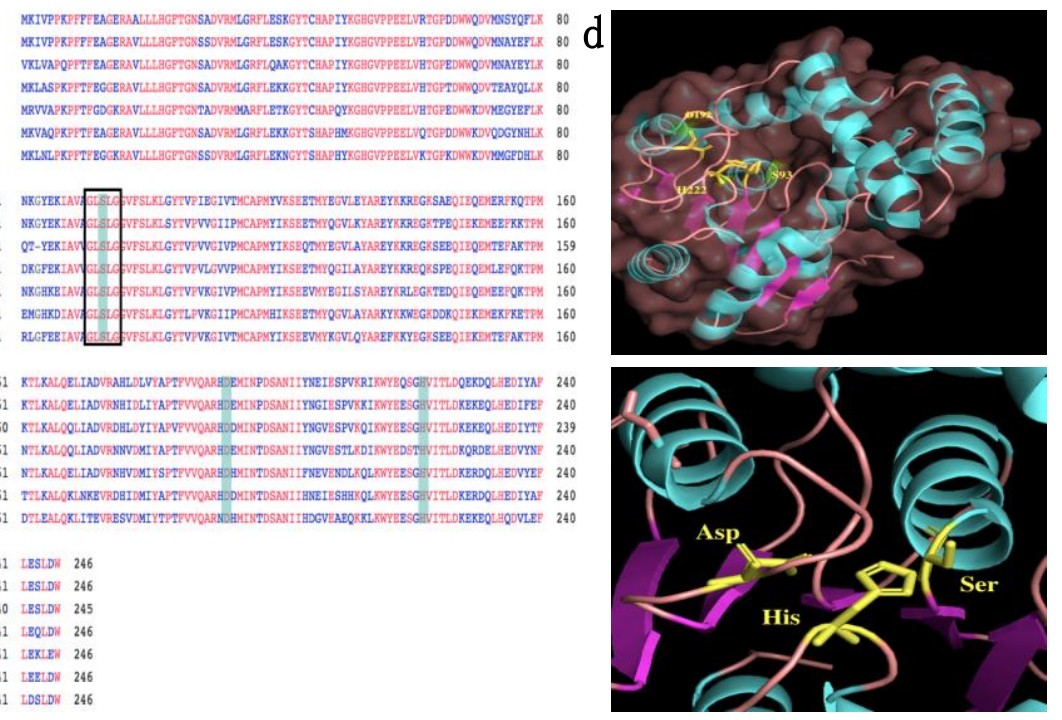

Figure 1. Screening and fermentation of wild type bacteria, gene analysis and molecular structure modeling of Est 741 . (a) Hydrolysis circle on esterase screening culture. (b) Enzyme activity and $\mathrm{OD}_{600}$ of the fermentation broth of the wild type bacteria. (c) Multiple sequence alignment between Est 741 and other closely related enzymes. The catalytic active sites are marked in blue, and the conserved region, GLSLG (Gly-Leu-Ser-Leu-Gly) is boxed. (d) 3D model of Est 741 was predicted by SWISS-MODEL (A fully automated protein structure homology-modelling server).

\subsection{Gene Analysis and Molecular Structure Modeling of Est741}

Information about the structure of Est741 protein was obtained by alignment analysis of proteins (Figure 1c) and the protein structure with catalytic triad was viewed in the Pymol Viewer (Figure 1d).

Compared with the detailed report on carboxylesterase, multi-sequence alignment between Est ${ }_{741}$ and closely related carboxylesterases revealed that Est ${ }_{741}$ from Geobacillus uzenensis 23175 was $74.8 \%$ identical to the esterase from Bacillus cereus [19] and $82.9 \%$ identical to the esterase from Anoxybacillus flavithermus [20]. A database search revealed that Est 741 , although similar to some esterase and hydrolase fold proteins, has no resemblance to any of the reported pyrethroid hydrolase enzymes.

\subsection{Cloning, Expression, and Purification of the Original Enzyme Est ${ }_{741}$ and the Mutant Enzyme Est $_{M 160 \mathrm{~K}}$}

In the E. coli BL21 (DE3) expression system, est ${ }_{741}$ was inserted into the His-tagged pET28a vector, and the strong T7 promoter was used to express the Est ${ }_{741}$ and Est ${ }_{\mathrm{M} 160 \mathrm{~K}}$. After purification, Est ${ }_{741}$ and Est $_{\mathrm{M} 160 \mathrm{~K}}$ showed specific activity of $460 \mathrm{U} / \mathrm{mg}$ under optimal conditions: $\mathrm{pH}$ 8.0, temperature $50{ }^{\circ} \mathrm{C}$, and p-nitrophenol hexanoate as a substrate. 
Similarly, in P. pastoris KM71, after coating the cells in MD (Minimal Dextrose) plates without histidine and performing PCR analysis using the primer AOX, transformants with a G418 concentration of $3 \mathrm{mg} / \mathrm{mL}$ were transferred to a BMMY (Buffered Methanol-complex Medium) plate containing $1 \%$ tributyrin, and colonies showing transparent hydrolysis zones were selected for subsequent fermentation (Figure S1). The specific activity of the supernatant in the fermentation broth of BMMY medium was $352 \mathrm{U} / \mathrm{mg}$. The optimal concentration of methanol for induction was $1 \%$ (Table 1 ). A lower methanol concentration does not induce the secretion of a large amount of protein by Pichia pastoris, and when the concentration of methanol is too high, it is toxic to cells and increases the cost of production [21]. The results showed that Est $_{741}$ is a pesticide-degrading enzyme with a relatively low molecular weight of $27.17 \mathrm{kDa}$ (Figure S2). Pichia pastoris has been extensively applied for protein expression owing to its multiple advantages such as secretory expression.

Table 1. Effect of different methanol concentrations on P. pastoris cell growth and enzyme activity.

\begin{tabular}{ccc}
\hline Methanol Concentration $(W / V, \%)$ & Dry Cell Weight $(\mathrm{g} / \mathrm{L})$ & Relative Activity $(\%)$ \\
\hline 0.5 & $86.30 \pm 0.28$ & $86.2 \pm 0.3$ \\
1.0 & $90.09 \pm 0.43$ & 100.0 \\
1.5 & $82.86 \pm 0.41$ & $91.3 \pm 0.6$ \\
\hline
\end{tabular}

Values represent the mean \pm standard deviation $(n=3)$. The activity measured under optimal conditions was set to $100 \%$.

\subsection{Enzymatic Properties of Est $741 /$ Est $_{M 160 K}$ and Analysis of the Change of Properties of the Mutant} Enzyme Est ${ }_{M 160 K}$

Optimization of conditions for the determination of Est $_{741}$ and Est $\mathrm{M}_{\mathrm{M} 160 \mathrm{~K}}$ after purification revealed that the enzymatic properties of the two were different. The optimal $\mathrm{pH}$ and optimal substrate for Est $_{741}$ and $\mathrm{Est}_{\mathrm{M} 160 \mathrm{~K}}$ were 8.0 and p-nitrophenyl hexanoate respectively (Figure 2a,b). The optimal temperature of Est ${ }_{\mathrm{M} 160 \mathrm{~K}}$ was $60^{\circ} \mathrm{C}$, which was $10^{\circ} \mathrm{C}$ higher than the optimum temperature of Est ${ }_{741}$ (Figure 2c). For short-chain nitrophenyl ester, the enzyme activity was higher, while for long chain nitrobenzene, phenyl esterase activity was low, especially no active with C14-C16 substrate. These results indicate that the purified enzyme is an esterase rather than a lipase.

The thermal stability of the purified Est 741 was determined by holding at different temperatures for different times. The results showed that $41.8 \%$ residual enzyme activity remained after $60 \mathrm{~h}$ of incubation at $60{ }^{\circ} \mathrm{C}$, but when the temperature was $70{ }^{\circ} \mathrm{C}$, only $20 \%$ of the maximum enzyme activity was observed after $2 \mathrm{~h}$ of incubation (Figure 2d). The same treatment was used to determine the thermal stability of the purified $\mathrm{Est}_{\mathrm{M} 160 \mathrm{~K}}$. Not much difference was observed in enzyme activity at $60{ }^{\circ} \mathrm{C}$, but temperature tolerance of Est ${ }_{\mathrm{M} 160 \mathrm{~K}}$ showed an enhanced $\mathrm{T}_{1 / 2}$ of $2.5 \mathrm{~h}$ in comparison to Est $_{741}(1.3 \mathrm{~h})$. By structure analysis, the mutant amino acid Met is on the surface of the enzyme molecule. As shown in Figure 3, Lys160 and Thr162 formed an additional hydrogen bond after mutation. Although the thermal stability was not improved greatly after mutation, the mutant enzyme with an optimum temperature of $60^{\circ} \mathrm{C}$ can be used as a thermophilic esterase. Bhawna et al. obtained the mutants, $\mathrm{t}_{1 / 2}$ of the best mutant lipases was only $1 \mathrm{~h}$ at $52{ }^{\circ} \mathrm{C}$ [22]. The results of thermal stabilities suggested that Est $_{\mathrm{M} 160 \mathrm{~K}}$ had a broad temperature range and excellent thermostability at $60{ }^{\circ} \mathrm{C}$.

In organic solvents, little effect on enzyme activities is observed. In the most polar solvent, methanol, 91.5\% activity was still observed. The results showed that $\mathrm{Ca}^{2+}$ and $\mathrm{Fe}^{2+}$ improved the activity of enzymes. In contrast, $\mathrm{Zn}^{2+}$ significantly reduced enzyme activity, while $\mathrm{Na}^{+}, \mathrm{Co}^{2+}$, and $\mathrm{Mn}^{2+}$ did not significantly affect enzyme activity. For practical applicability, the effects of various surfactants and organic solvents on the activity of Est $_{\mathrm{M} 160 \mathrm{~K}}$ were also determined; the results showed that these surfactants and solvents had a negative effect on its enzyme activity. Sodium dodecyl sulfate (SDS) and Tween 20 had almost no effect on enzyme activity, cetyltrimethylammonium bromide (CTAB) and Triton X-100 greatly reduced the activity, and ethylene diamine tetraacetic acid (EDTA) improved the activity (Table 2). Biochemical analysis showed that the new carboxylesterase Est $_{\mathrm{M} 160 \mathrm{~K}}$ was a good 
new biocatalyst. The reaction process did not require metal ions or other cofactors and has a certain tolerance to organic solvents. The chelating agent EDTA and surfactant SDS had little effect on enzyme activity. In practice, wastewater contains a lot of metal ions, and most pesticides are in the form of emulsifiable concentrates. Surfactants and organic solvents are essential for the study of the effects of Est $_{\mathrm{M} 160 \mathrm{~K}}$ enzyme activity. From the results, Est $_{\mathrm{M} 160 \mathrm{~K}}$ is suitable for industrial applications and can be used as an alternative to chemical catalysts for wastewater treatment $[23,24]$.
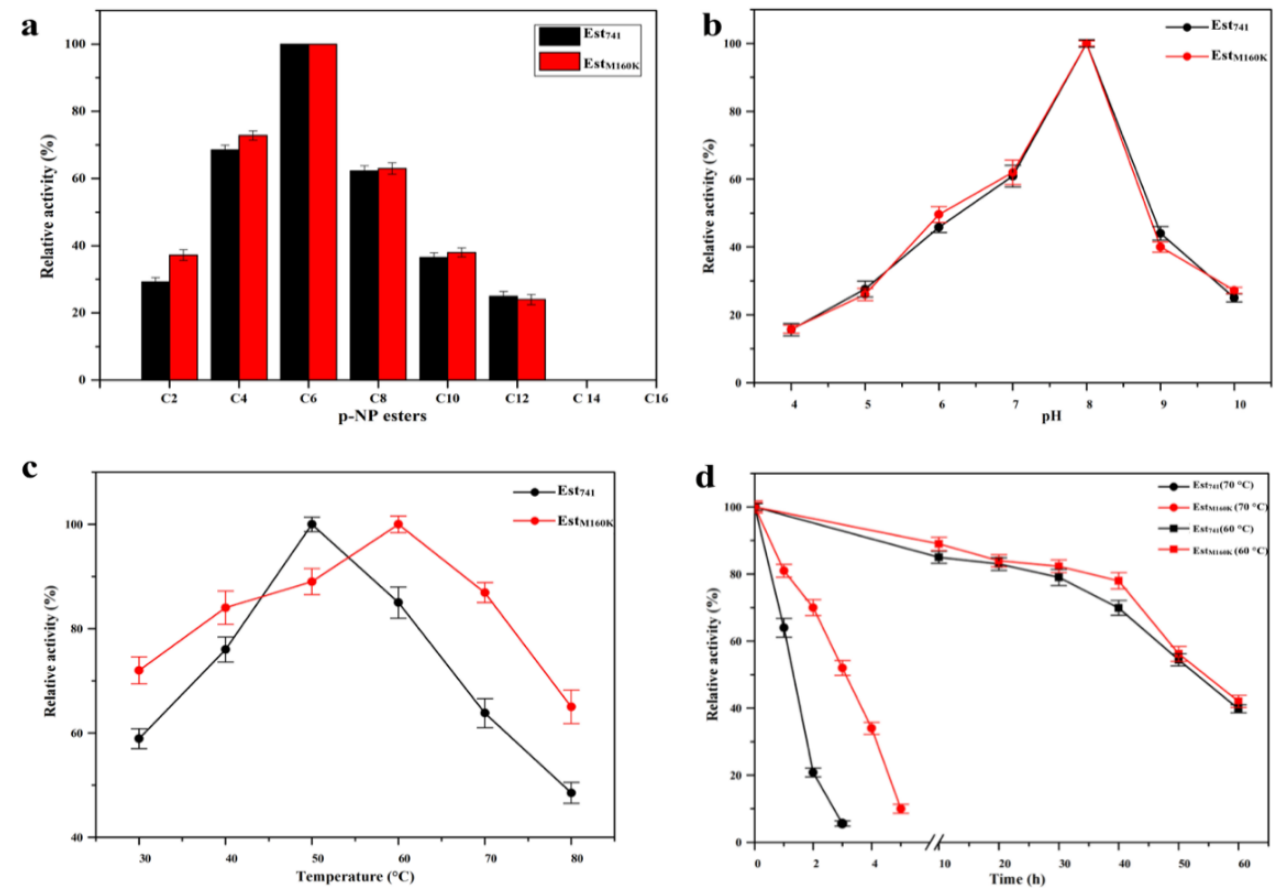

Figure 2. Characterization of Est ${ }_{741}$ and $\mathrm{Est}_{\mathrm{M} 160 \mathrm{~K}}$. (a) Effect of p-nitrophenyl (p-NP) esters of different chain lengths on the activities of Est 741 and Est $\mathrm{M}_{\mathrm{M} 160 \mathrm{~K}}$. (b) Effect of $\mathrm{pH}$ on the activities of Est $\mathrm{Bt}_{71}$ and Est $_{\mathrm{M} 160 \mathrm{~K}}$. (c) Effect of temperature on the activities of Est ${ }_{741}$ and Est ${ }_{\mathrm{M} 160 \mathrm{~K}}$. (d) Thermal stabilities of Est $_{741}$ and Est $_{\mathrm{M} 160 \mathrm{~K}}$ at 60 and $70{ }^{\circ} \mathrm{C}$.
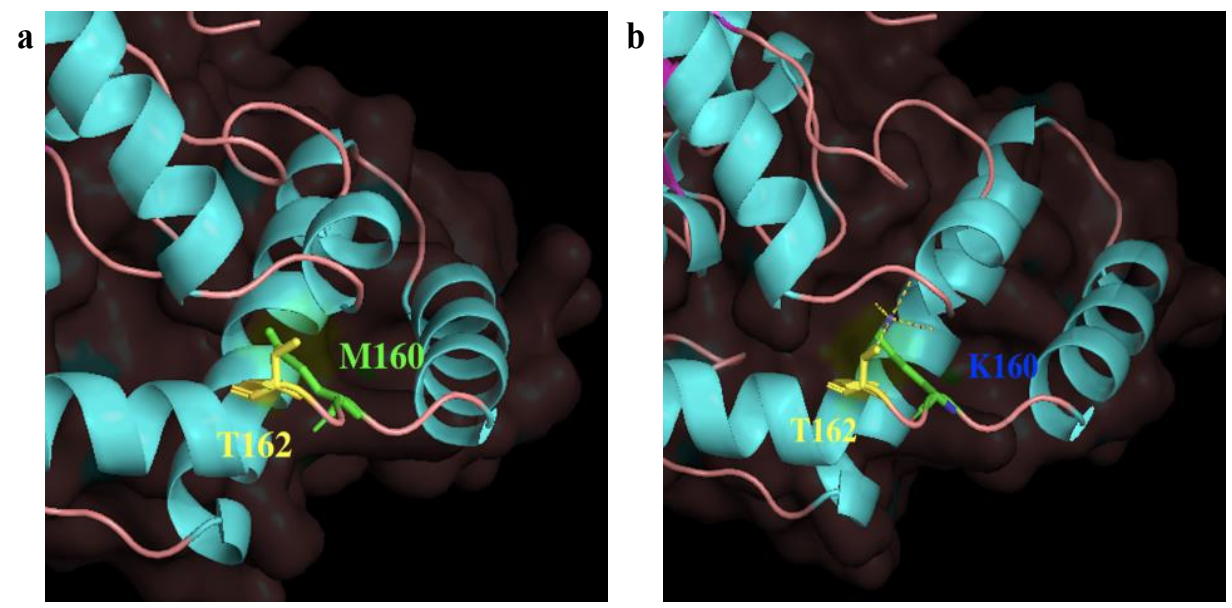

Figure 3. Structural analysis after site-directed mutagenesis using Pymol. (a) Three-dimensional structure of Est ${ }_{741}$ before mutation. (b) Three-dimensional structure of Est ${ }_{\mathrm{M} 160 \mathrm{~K}}$ after mutation. 
Table 2. Effects of additives on Est $_{\mathrm{M} 160 \mathrm{~K}}$ activity.

\begin{tabular}{cccccc}
\hline $\begin{array}{c}\text { Organic } \\
\text { Solvents }\end{array}$ & $\begin{array}{c}\text { Residual } \\
\text { Activity (\%) }\end{array}$ & Ion & $\begin{array}{c}\text { Residual } \\
\text { Activity (\%) }\end{array}$ & $\begin{array}{c}\text { Surfactants } \\
\text { and EDTA }\end{array}$ & $\begin{array}{c}\text { Residual } \\
\text { Activity (\%) }\end{array}$ \\
\hline Control & $100 \pm 0$ & $\mathrm{Control}$ & $100 \pm 0$ & Control & $100 \pm 0$ \\
Methanol & $91.5 \pm 2.5$ & $\mathrm{Mg}^{2+}$ & $89.5 \pm 3.1$ & Tween20 & $93.8 \pm 2.2$ \\
Ethanol & $75.6 \pm 2.3$ & $\mathrm{Cu}^{2+}$ & $85.2 \pm 2.6$ & Tween60 & $90.8 \pm 2.0$ \\
Acetonitrile & $63.8 \pm 2.3$ & $\mathrm{Ca}^{2+}$ & $103.4 \pm 1.8$ & Tween80 & $87.8 \pm 1.9$ \\
Isopropanol & $71.1 \pm 1.9$ & $\mathrm{Mn}^{2+}$ & $97.0 \pm 2.2$ & SDS & $92.4 \pm 2.5$ \\
Acetone & $87.9 \pm 1.5$ & $\mathrm{Zn}^{2+}$ & $76.1 \pm 3.7$ & TritonX-100 & $43.5 \pm 3.5$ \\
n-hexane & $73.2 \pm 2.9$ & $\mathrm{Co}^{2+}$ & $92.7 \pm 2.9$ & EDTA & $103.2 \pm 3.1$ \\
n-propanol & $72.5 \pm 3.2$ & $\mathrm{Na}^{+}$ & $94.5 \pm 3.3$ & & \\
Isooctane & $76.4 \pm 2.6$ & $\mathrm{Fe}^{3+}$ & $102.8 \pm 2.4$ & & \\
Benzene & $61.8 \pm 2.2$ & & & & \\
\hline
\end{tabular}

\subsection{Study of the Properties of Immobilized $l x$-Est ${ }_{M 160 K}$}

SEM showed that Est ${ }_{\mathrm{M} 160 \mathrm{~K}}$ was successfully immobilized on epoxy resin material lx-105s (Figure S3). The surface is very smooth before immobilization. After immobilization, the surface had a loose and uneven structure, which confirms that the immobilization of the carboxylesterase Est $\mathrm{M}_{\mathrm{M} 160 \mathrm{~K}}$ to the resin is caused by a chemical reaction between the enzyme and the epoxy group. Studies have reported that lipase B from Candida antarctica (CaLB) immobilized on epoxy resins materials such as Purolite ${ }^{\circledR}$ ECR8205F demonstrated higher specific activity and was comparable to the commercial preparation Novozyme 435 [25]. The new biocatalyst lx-Est ${ }_{\mathrm{M} 160 \mathrm{~K}}$ by immobilizing Est $_{\mathrm{M} 160 \mathrm{~K}}$ on the new epoxy resin $1 x-105$ s was obtained.

The effects of the esterase fixation time and buffer ionic strength on enzyme loading and relative enzyme activity were investigated. The optimal time for esterase fixation was $14 \mathrm{~h}$ (Figure $4 \mathrm{a}$ ). The efficiency reached about $78.5 \mathrm{mg} / \mathrm{g}$. By increasing the time from 14 to $20 \mathrm{~h}$, the relative enzyme activity was gradually reduced, and the load tends to be stable. This may be due to the fact that when the load reaches the maximum at $14 \mathrm{~h}$, subsequent shaking causes a decrease in enzyme activity. A buffer with higher ionic strength helps to enhance the covalent attachment of the enzyme. When the ionic strength of the buffer is high, the esterase conformation is easy to move and is more easily combined with the epoxy resin. However, when the ionic strength is too high, it is not suitable for general production applications [26,27]. Therefore, for subsequent studies, the ionic strength was finalized at $1.0 \mathrm{~mol} / \mathrm{L}$ (Figure $4 \mathrm{~b}$ ). The optimal $\mathrm{pH}$ of $1 \mathrm{x}-\mathrm{Est}_{\mathrm{M} 160 \mathrm{~K}}$ is 8.0 , and the result of the optimal $\mathrm{pH}$ is basically the same as that of the $\mathrm{Est}_{741}$ and $\mathrm{Est}_{\mathrm{M} 160 \mathrm{~K}}$. The thermal stability of $1 \mathrm{x}-\mathrm{Est}_{\mathrm{M} 160 \mathrm{~K}}$ is quite different from that of $\mathrm{Est}_{\mathrm{M} 160 \mathrm{~K}}$. The maximal specific activity $(36.11 \mathrm{U} / \mathrm{mg})$ of lx-Est $\mathrm{M}_{\mathrm{M} 60 \mathrm{~K}}$ occurred at $\mathrm{pH} 8.0$ with a protein loading of $78.5 \mathrm{mg} / \mathrm{g}$. It showed better thermal stability than free $\mathrm{Est}_{\mathrm{M} 160 \mathrm{~K}}$ (Figure 4c). After the immobilized enzyme lx-Est ${ }_{\mathrm{M} 160 \mathrm{~K}}$ was incubated at $70^{\circ} \mathrm{C}$ for $48 \mathrm{~h}$, the temperature tolerance of the lx-Est ${ }_{\mathrm{M} 160 \mathrm{~K}}$ showed an enhanced $\mathrm{T}_{1 / 2}$ of $36.8 \mathrm{~h}$ at $70{ }^{\circ} \mathrm{C}$ in comparison to Est $_{741}(1.3 \mathrm{~h})$, $\mathrm{T}_{1 / 2}$ of immobilized enzyme lx-Est $\mathrm{M}_{\mathrm{M} 160 \mathrm{~K}}$ showed an enhanced $34.3 \mathrm{~h}$ more than Est $\mathrm{M}_{160 \mathrm{~K}}$. The higher thermostability of the immobilized enzymes is due to additional covalent bonding in the tertiary and secondary structures that prevents their denaturation at high temperatures. When the epoxy resin is modified by the metal chelate method, the immobilized enzyme $1 \mathrm{x}$-Est ${ }_{\mathrm{M} 160 \mathrm{~K}}$ exhibits excellent thermal stability [28]. The immobilized lx-Est ${ }_{\mathrm{M} 160 \mathrm{~K}}$ exhibited high operational stability and maintained $72 \%$ initial activity after continuous reaction of 10 batches degradation of bifenthrin pesticides (Figure $4 \mathrm{~d}$ ). Even in wet conditions, the epoxy resin-immobilized lx-Est ${ }_{\mathrm{M} 160 \mathrm{~K}}$ was found to be very stable, and it can be stored for a long time. 1x-Est $\mathrm{M}_{\mathrm{M} 60 \mathrm{~K}}$ could play an advantage in the recycling of wastewater treatment $[29,30]$. The high potential of the industrial application of the enzyme was demonstrated in all the reactions carried out in this study. 
a

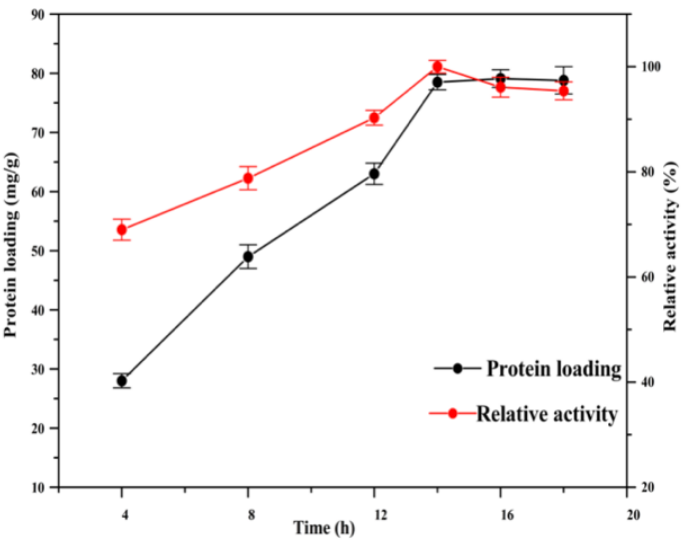

c

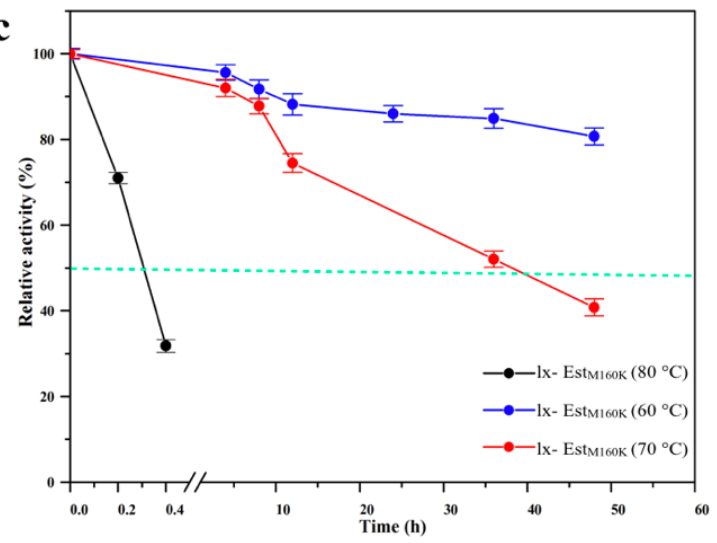

b

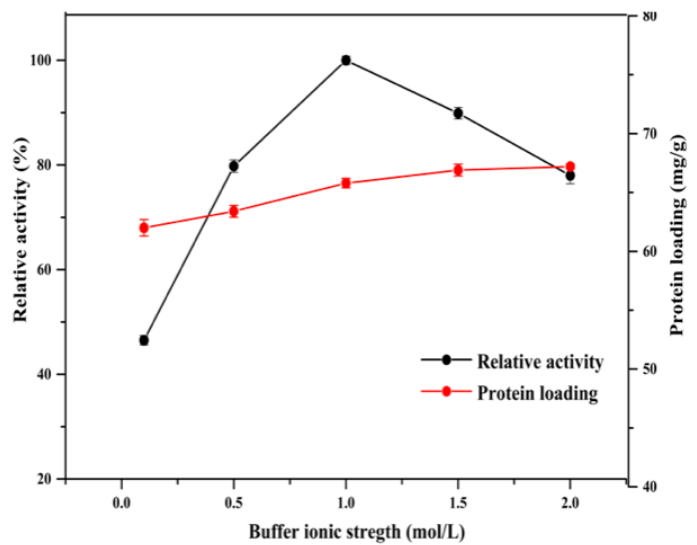

d

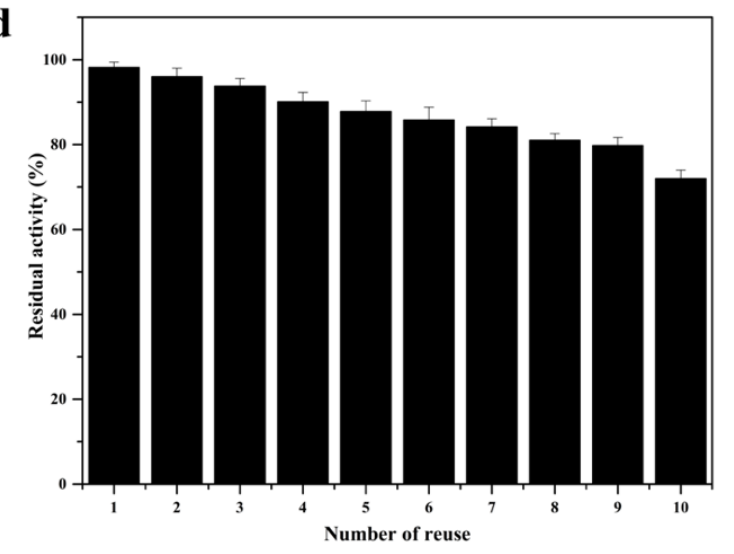

Figure 4. Optimization of Est $\mathrm{M}_{\mathrm{M} 160 \mathrm{~K}}$ immobilization and performance of 1x-Est $\mathrm{M}_{\mathrm{M} 160 \mathrm{~K}}$. (a) Effect of the immobilization time on enzyme stability. (b) Effect of buffer ionic strength on immobilization. (c) Thermal stability of immobilized Est $_{\mathrm{M} 160 \mathrm{~K}}$. (d) Reusability of immobilized lx-Est $\mathrm{M}_{\mathrm{M} 160 \mathrm{~K}}$.

\subsection{Degradation of Organophosphorus Pesticide Malathion}

In order to study the effect of the initial concentration of malathion on its degradation, different concentrations of malathion $(10-50 \mathrm{mg} / \mathrm{L})$ were used in a $10 \mathrm{~mL}$ stoppered flask reaction system. Due to the complexity of the TLC chromogenic method, the study was validated using commercially available malathion residue test strips. The standard showed no color on the test paper, indicating the presence of malathion and the concentration exceeded $1 \mathrm{mg} / \mathrm{L}$. The concentration of malathion after the reaction could initially be observed by the intensity of the color of the test paper, the deepest blue was shown by the blank group without malathion. When the concentration of malathion was $20 \mathrm{mg} / \mathrm{L}$ and the reaction temperature was $60^{\circ} \mathrm{C}$, after $40 \mathrm{~min}$ of reaction of $50 \mathrm{U}$ immobilized enzyme lx-Est ${ }_{\mathrm{M} 160 \mathrm{~K}}$, the maximum malathion removal was $95.8 \%$ (Figure $\mathrm{S} 4$ ). This indicates that Est $\mathrm{M}_{\mathrm{M} 160 \mathrm{~K}}$ has the ability to degrade the organophosphorus pesticide malathion. Further, the peak time of malathion at 6.2 min was determined by HPLC and performed quantitative analysis, confirming that the carboxylesterase Est 741 can degrade malathion. Although many bacteria with malathion hydrolase activity have been studied [31], this is the first report on the degradation of malathion by carboxylesterase from Geobacillus uzenensis. The enzyme Est ${ }_{\mathrm{M} 160 \mathrm{~K}}$ also showed greater degradation of malathion than the carboxylesterase D1CarE5 from Alicyclobacillus [32]. Malathion is commonly used to control mosquitos and a variety of insects and is listed by the US Environmental Protection Agency (USEPA) as toxicity class III [33]. Est ${ }_{\mathrm{M} 160 \mathrm{~K}}$ as a novel enzyme that can efficiently degrade malathion is important for practical applications. Further research on the degradation of other pesticides by Est $_{\mathrm{M} 160 \mathrm{~K}}$ and its underlying mechanisms is ongoing. 


\subsection{Degradation of Pyrethroid Pesticide Wastewater in Packed-Bed Column Reactor}

Firstly, the hydrolysis rate of three kinds of pesticides was tested by using immobilized enzyme 1x-Est ${ }_{\mathrm{M} 160 \mathrm{~K}}$ (Figure 5a) in a $10 \mathrm{~mL}$ stoppered flask reaction system. 1x-Est ${ }_{\mathrm{M} 160 \mathrm{~K}}$ could degrade bifenthrin with high efficiency, followed by fenpropathrin, and then fenvalerate (Table S1). The degradation results of the other two pesticides are not shown in this paper. For further practical applications, the conditions of common sewage were simulated, using a $10 \mathrm{~mL}$ packed-bed column reactor to degrade bifenthrin, and tested the degradation ability of $1 \mathrm{x}$-Est $\mathrm{E}_{\mathrm{M} 160 \mathrm{~K}}$ on pyrethroid pesticide wastewater (Figure $5 \mathrm{~b}$ ). The substrate flows upwards from the bottom of the reactor, through the membrane, and reacts with the immobilized enzyme lx-Est ${ }_{\mathrm{M} 160 \mathrm{~K}}$. The amount of the immobilized enzyme, substrate concentration, and feed flow rate are key parameters in a continuous reaction [34]. The results showed that when $2.5 \mathrm{~g}$ of immobilized enzyme $1 \mathrm{x}-\mathrm{Est}_{\mathrm{M} 160 \mathrm{~K}}$ was charged into a $10 \mathrm{~mL}$ column reactor, reaction temperature was $60^{\circ} \mathrm{C}$, pump speed was $0.7 \mathrm{~mL} / \mathrm{min}$ (optimization data is not displayed), and the initial removal rate of bifenthrin reached $90.4 \%$ when the concentration of bifenthrin was $500 \mathrm{mg} / \mathrm{L}$. The simplified diagram of the reaction apparatus for degrading bifenthrin is shown in Figure 5b. The catalytic stability of the resin is a key parameter for regeneration of the resin used in the continuous catalytic reaction. The important advantage of the resin catalysts is suitable to continuously produce biodiesel and good results were achieved [35]. However, the operation stability of the reactor and the regeneration of resins were not ideal [36]. In this study, the performances of a laboratory-scale reactor (packed-bed reactor) treating bifenthrin using immobilized enzyme lx-Est ${ }_{\mathrm{M} 160 \mathrm{~K}}$ were investigated. The results obtained in the present study demonstrate that PBR can promote enhanced bifenthrin removal from synthetic wastewater and has good operation stability. In the wastewater treatment process, the degradation of the pesticide and the hydrolysis of the oil in the wastewater are simultaneously achieved (Figure 5c). There are no literature reports on biological treatment of bifenthrin in a PBR to compare with this study and little information concerned the degradation of high bifenthrin concentration. This experiment realized the treatment of $500 \mathrm{mg} / \mathrm{L}$ bifenthrin wastewater in a laboratory-scale packed-bed reactor.

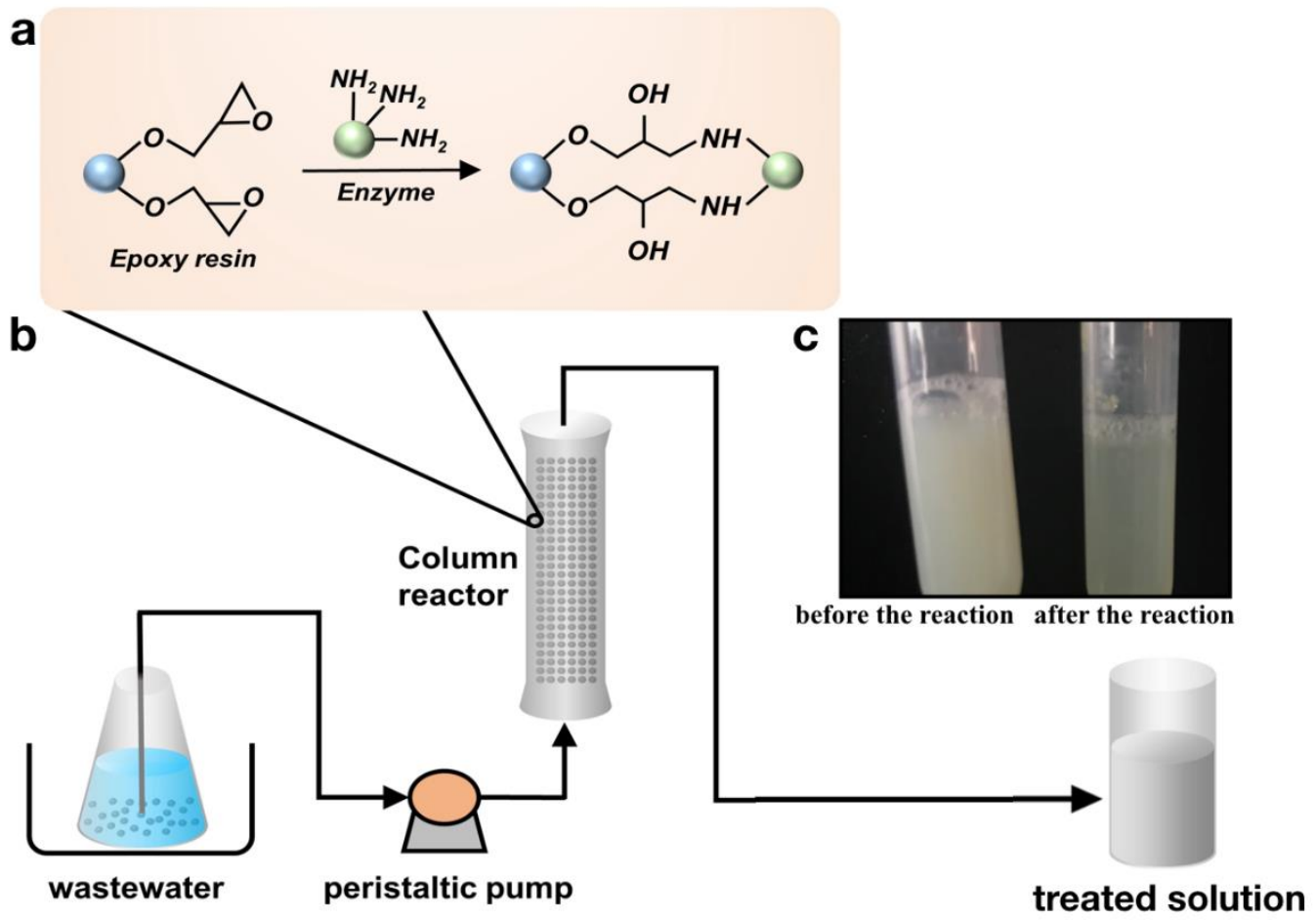

Figure 5. A schematic of the packed-bed bioreactor for the biodegradation of bifenthrin. (a) Est $\mathrm{M}_{\mathrm{M}} 60 \mathrm{~K}$ immobilization on epoxy resin 1x-105s. (b) Experimental set-up of packed bed reactor (PBR) used for continuous degradation of bifenthrin wastewater by $1 x-$ Est $_{\mathrm{M} 160 \mathrm{~K}}$. (c) Picture of samples before and after degradation of bifenthrin wastewater by lx-Est $\mathrm{M}_{\mathrm{M} 160 \mathrm{~K}}$. 


\section{Materials and Methods}

\subsection{Materials}

Site-directed mutagenesis kit Mut Express ${ }^{\circledR}$ II Fast Mutagenesis Kit V2 was purchased from Vazyme (Nanjing, China). The epoxy resin 1x-105s used for immobilization was from Xi-an Lanxiao Technology New Material Co., Ltd. (Xi-an, China). The p-nitrophenyl (p-NP) ester substrates, glyceryl tributyrate, fenpropathrin, fenvalerate, and bifenthrin were purchased from Sigma (St. Louis, MO, USA). Malathion standard was purchased from the National Standards Center (Shanghai, China). Different concentrations of pesticide-contaminated wastewater were simulated by adding different concentrations of commercially available pesticides to domestic wastewater. Malathion quick test card was purchased from Guangzhou Oasis Food Safety Technology, Co. Ltd. (Guangzhou, China). All other chemicals were of analytical grade or HPLC grade, and purchased from local markets.

\subsection{Plasmids and Strains}

pET-28a (Novagen, Madison, WI, USA) and the plasmid pPIC9K (Invitrogen, Madison, WI, USA) were applied for constructing the expression plasmids. Strain Geobacillus uzenensis 23175 was purchased from Deutsche Sammlung von Mikroorganismen und Zellkulturen GmbH (DSM23175). E. coli DH5 $\alpha$ (Invitrogen, USA), E. coli BL21(DE3) (Invitrogen, USA), and P. pastoris strain KM71 were used for gene cloning and expression.

\subsection{Fermentation of Wild Strain}

In this work, an LB plate supplemented with 1\% tributyrin was used to screen different thermophiles with esterase activity. The strains with large hydrolytic circle were selected (Geobacillus uzenensis 23175 was selected in this work). The selected hydrolyzed strain was fermented to detect its growth state and enzyme-producing properties, and $1 \mathrm{~mL}$ of fermentation broth was taken in an EP tube every 2 or 4 h, 3 tubes each time, and the $\mathrm{OD}_{600}$ and enzyme activity of supernatant was measured.

\subsection{Sequence Analysis of Est741}

The nucleotide sequence and predicted amino acid sequence were analyzed by the programs of Blast (https://blast.ncbi.nlm.nih.gov/Blast.cgi), and only sequences previously cloned and with high homology were used. Multiple sequence alignments were performed using DNAMAN and CLUSTAL W (A sequence alignment tool for nucleic acid sequences). Model-building was developed by SWISS-MODEL (http://swissmodel.expasy.org/SWISS-MODEL.htmL), and carboxylesterase from Geobacillus stearothermophilus (PDB (Protein Data Bank) 1R1D) was used as the template. The Pymol (https://pymol.org/2/) was adopted for the analysis of protein structure information. Analysis of mutant carboxylesterase was carried out using PoPMuSiC (https://soft.dezyme.com/login) and PymoL. The GenBank accession number of $e^{2} t_{741}$ is MN752403.

\subsection{Expression and Purification of Recombinant Carboxylesterase in E. coli and P. pastoris}

The $e t_{741}$ gene $(741 \mathrm{bp})$ was obtained by PCR using the primers Est 741 -U and Est 741 -D, using the G. uzenensis 23175 genome as a template (Table S2). The ester gene was reclaimed and connected with pET-28a. Then, pET-28a-Est 741 was transformed into E. coli BL21 (DE3). The cells were induced by IPTG at $20^{\circ} \mathrm{C}$ and cultured in a shaker for $20 \mathrm{~h}$. After centrifugation at $8000 \times g$ for $10 \mathrm{~min}$ at $4{ }^{\circ} \mathrm{C}$ and resuspension in buffer, the harvested cells were lysed by sonication then centrifuged at $8000 \times g$ for $10 \mathrm{~min}$ to separate insoluble matter, the supernatant was then centrifuged through a $0.22 \mu \mathrm{m}$ filter and transferred to a Ni-NTA superflow column. The eluted protein was desalted and concentrated by ultrafiltration using a $50 \mathrm{~mL}$ Amicon Ultra Centrifugal Filter Device (Millipore, Billerica, MA, USA).

For P. pastoris expression, the gene was amplified by the primers Est $741-\mathrm{F}$ and Est $741-\mathrm{R}$, the PCR product was cloned into pPIC9K. The obtained correct plasmid was linearized by Sal I and purified, 
then transferred to the competent state of KM71 cells by electroporation at $1.5 \mathrm{kV}$. The transformants grew on MD plates at $30^{\circ} \mathrm{C}$ for 2-3 days. After 3-5 days of incubation on YPD solid plates containing different concentrations of G418, high copy number and high expression strains was screened, and transferred the transformants capable of growing on $3 \mathrm{mg} / \mathrm{mL}$ G418 concentration plates to BMMY solid plates containing tributyrin for further screening. Finally, the cells were transferred to BMMY with different methanol concentrations to induce heterologous protein Est ${ }_{741}$ expression for 4 days. Then, the fermentation supernatant was centrifuged at $8000 \times g$ for $5 \mathrm{~min}$ as the final catalyst. All the purification steps were carried out at $4{ }^{\circ} \mathrm{C}$. Crude extracts and pure enzymes were analyzed by sodium dodecyl sulfate polyacrylamide gel electrophoresis (SDS-PAGE), and protein concentration was determined by the Bradford method with BSA (Bovine serum albumin) as the standard.

\subsection{Analysis of the Enzymatic Properties of Est 741}

The optimal temperature, $\mathrm{pH}$, and substrate of Est 741 were determined by a single variable method. The optimal substrate was determined by examining the ability of the enzyme to hydrolyze various p-nitrophenyl ester (C2-C16) substrates; enzyme assays were carried out under standard assay conditions. The optimal $\mathrm{pH}$ was determined by measuring the enzyme activity at $50{ }^{\circ} \mathrm{C}$ with $\mathrm{C} 6$ as the substrate and in different buffers with $\mathrm{pH}$ ranging from 4.0 to $10.0(\mathrm{pH} 4.0-5.0$ with $50 \mathrm{mM}$ citric acid-sodium citrate, $\mathrm{pH}$ 6.0-7.0 with $50 \mathrm{mM}$ sodium phosphate, $\mathrm{pH} 8.0$ with $50 \mathrm{mM}$ Tris-HCl, and $\mathrm{pH} 9.0-10.0$ with $50 \mathrm{mM}$ glycine- $\mathrm{NaOH}$ ). The optimal reaction temperature of the enzyme was measured by using Tris- $\mathrm{HCl}$ buffer with $\mathrm{pH} 8.0$ with $\mathrm{C} 6$ as substrate, and the temperature gradient was $30-80^{\circ} \mathrm{C}$. The thermostability of Est 741 was evaluated by incubating the enzyme for $60 \mathrm{~h}$ at the optimal temperature to determine its residual activity. Aliquots were taken at different intervals, and the residual esterase activity was determined. A control (the enzyme before incubation) was used to determine $100 \%$ activity. The enzyme activity experiment was repeated three times.

The effect of metal ions on enzyme activity was determined by adding $10 \mathrm{mM}$ metal ions $\left(\mathrm{Mg}^{2+}\right.$, $\mathrm{Cu}^{2+}, \mathrm{Ca}^{2+}, \mathrm{Mn}^{2+}, \mathrm{Zn}^{2+}, \mathrm{Co}^{2+}, \mathrm{Na}^{+}$, and $\left.\mathrm{Fe}^{3+}\right)$ to the reaction system, followed by incubation at the optimal temperature for $1 \mathrm{~h}$. Surfactants ( $1 \% v / v$; SDS, CTAB, Tween-20, Tween-80, and TritonX-100) and the chelating agent EDTA were added to the reaction system followed by incubation at the optimal temperature for $1 \mathrm{~h}$ and measurement of residual activity to determine their effect on enzyme activity. To determine the tolerance of the enzyme to organic solvents, an aliquot of the recombinase was treated with $30 \%$ organic solvent (methanol, ethanol, acetonitrile, isopropanol, acetone, n-hexane, n-propanol, isooctane, and benzene) for $2 \mathrm{~h}$. A sample of the enzyme without any additives was considered as control $(100 \%)$, and the residual activity was measured. The enzyme activity measured after different temperature treatments is relative residual enzyme activity. The time corresponding to $50 \%$ of the initial activity under continuous measurement conditions was $\mathrm{T}_{1 / 2}$.

The enzyme activity was measured under standard conditions as per the standard protocol (reaction at the optimum temperature for $5 \mathrm{~min}$ and measurement of absorbance at $405 \mathrm{~nm}$ ). Enzyme activity was calculated at $\mathrm{OD}_{405}$ as per the standard curve of p-nitrophenol. One unit of carboxylesterase activity $(\mathrm{U})$ is defined as the amount of enzyme that releases $1 \mu \mathrm{mol}$ of $\mathrm{p}-\mathrm{NP}$ per min under assay conditions. Each experiment included three repetitions [37], and the average of three replicate measurements was used as each activity value.

\subsection{Improving the Enzymatic Properties of Est 741 by Site-Directed Mutagenesis}

Through online prediction, the appropriate site was selected for site-directed mutagenesis. Primers (Est $\mathrm{M}_{160 \mathrm{~K}}-\mathrm{tF}$ and $\mathrm{Est}_{\mathrm{M} 160 \mathrm{~K}}-\mathrm{tR}$ ) were designed to introduce mutations into the carboxylesterase gene by a site-directed mutagenesis kit; and the variant was expressed and purified in E. coli BL21(DE3) and P. pastoris. Mutants with high hydrolytic activity were screened by using tributyrin as a substrate for induction of expression. The enzymatic properties after the mutation were then determined in the same manner as for the original enzyme, and the enzymatic properties of the mutant were compared 
with those of the wild type. The mutation site was further analyzed through three-dimensional structural model construction using SWISS-MODEL and Pymol.

\subsection{Immobilization of the Recombinant Esterase on Epoxy Resin and Determination of the Properties of the Enzyme}

The immobilized Est $\mathrm{M}_{\mathrm{M} 160 \mathrm{~K}}$ was prepared as per the existing method. After the purified enzyme solution was passed through a $10 \mathrm{kDa}$ molecular weight ultrafiltration membrane, Est $_{\mathrm{M} 160 \mathrm{~K}}$ was immobilized according to the following procedure: epoxy resin $1 \mathrm{x}-105 \mathrm{~s}$ was activated with a different ion buffer (100 mM-2M Tris-HCl buffer pH8.0), $1 \mathrm{~g}$ epoxy resin was placed in a $250 \mathrm{~mL}$ Erlenmeyer flask, and $100 \mathrm{mg}$ purified Est ${ }_{\mathrm{M} 160 \mathrm{~K}}$ enzyme was packed at $200 \mathrm{rpm}$ and $20^{\circ} \mathrm{C}$ for $4-20 \mathrm{~h} \mathrm{[38].} \mathrm{After} \mathrm{fixation,}$ the suspension was filtered and the resin was washed with a buffer until no enzyme activity was detected in the eluate. Finally, the immobilized carboxylesterase was vacuum-dried for $12 \mathrm{~h}$ and stored at $4{ }^{\circ} \mathrm{C}$ until further use. The immobilized lx-Est ${ }_{M 160 K}$ was characterized by scanning electron microscopy (SEM), and SEM images were acquired using an S-3400N scanning electron microscope (Hitachi, Japan). The protein loading of the immobilized lx-Est ${ }_{\mathrm{M} 160 \mathrm{~K}}$ was determined using the Bradford method, and the enzyme activity recovery rate was calculated by measuring the enzyme activity before and after immobilization. The method for measuring the activity of the immobilized enzyme was the same as that of the free enzyme [39]. The residual hydrolysis activity of the immobilized enzyme was measured at different temperatures $\left(60,70\right.$, and $\left.80^{\circ} \mathrm{C}\right)$ to determine the thermal stability of the immobilized ester. The recyclability of immobilized enzymes was further investigated. Then, $10 \mathrm{~mL}$ of effluent was collected at each reaction time when the effluent solution from the outlet of reactor was introduced into a collection tube and then proceeded to the next batch of reactions. At the end of the reaction, natural sedimentation was used to separate the immobilized carboxylesterase from the mixture. The esterase was washed with buffer and reused under the same conditions; the hydrolysis capacity of each batch for bifenthrin degradation was calculated.

\subsection{Self-Made Radial Packed-Bed Column Reactor and Degradation of Pesticides}

The self-made small column reactor is made of polyvinyl chloride tube with a total volume of $10 \mathrm{~mL}$. The appropriate amount of immobilized enzyme $1 \mathrm{x}$-Est $\mathrm{M}_{\mathrm{M} 60 \mathrm{~K}}$ is placed in the reactor and passed through a peristaltic pump BT1002 (LongerPump, Hebei, China). A certain rate $(0.7 \mathrm{~mL} / \mathrm{min}$ ) of substrate, which was incubated at $60^{\circ} \mathrm{C}$, was pumped into the reactor to verify the feasibility of the reactor. After the reaction was completed, the immobilized enzyme particles in the reactor were washed three times with the buffer solution, and then the above operation was repeated to continue the next batch of reactions. Enzyme activity obtained in the initial batch of reactions was defined as $100 \%$, and the reaction was repeated 10 times to test the number of times the immobilized enzyme could be reused.

The degradation conditions of the organophosphorus pesticide malathion were as follows: the reaction system was in a $10 \mathrm{~mL}$ stoppered flask, the final concentration of malathion was 10 to $50 \mathrm{mg} / \mathrm{L}$, a certain amount of immobilized enzyme lx-Est ${ }_{\mathrm{M} 160 \mathrm{~K}}$ was added, the reaction time was $100 \mathrm{~min}$, sampling was conducted every $20 \mathrm{~min}$, and the experiment was repeated three times for each sample. The reaction solution was extracted twice with $n$-hexane [40]. After centrifugation at $12,000 \times g$ for $10 \mathrm{~min}$, the supernatant was aspirated into a new EP (Eppendorf)tube, and n-hexane in the supernatant was evaporated and finally the sample is dissolved in methanol. Standard malathion was used as the control group and processed in the same way. The standard curve of malathion is shown in Figure S5. The test strips of malathion residues purchased in the market were initially tested for malathion content in the samples. The HPLC conditions for measuring malathion degradation were as follows: Agilent ZORBAX Eclipse XDB C18 (Chromatographic column), column temperature $30^{\circ} \mathrm{C}$, mobile phase: methanol: water $68.5: 31.5(v / v)$, and flow rate $1.0 \mathrm{~mL} / \mathrm{min}$. The sample was filtered through a $0.45 \mu \mathrm{m}$ filter, and the injection volume was $20 \mu \mathrm{L}$ and the detection wavelength was $220 \mathrm{~nm}$ [41]. 
Pyrethroid degradation conditions were used to evaluate the ability of lx-Est ${ }_{\mathrm{M} 160 \mathrm{~K}}$ to degrade bifenthrin. Firstly, a preliminary experiment was carried out in a $10 \mathrm{~mL}$ reaction system. Immobilized enzyme lx-Est $_{\mathrm{M} 160 \mathrm{~K}}(2.5 \mathrm{~g})$ was added to a standard pesticide solution to a final concentration of $100-800 \mathrm{mg} / \mathrm{L}$, and reacted at $150 \mathrm{rpm}$ and $50{ }^{\circ} \mathrm{C}$ for $20-100 \mathrm{~min}$, with sampling every $20 \mathrm{~min}$. After adjusting the $\mathrm{pH}$ of the $1 \mathrm{M} \mathrm{HCL}$ solution to 3.0, the lower organic phase was collected by extracting twice with an equal volume of dichloromethane. Then dichloromethane is evaporated from the solution, and finally the sample is dissolved in methanol [42]. A wastewater sample containing bifenthrin $500 \mathrm{mg} / \mathrm{L}$ was used for the same treatment method. UV-Vis absorption spectrum of bifenthrin, physical picture of degradation reactor and HPLC detection results was shown in Figure S6. The liquid chromatographic conditions were as follows: ZORBAX Eclipse XDB C18, column temperature $25^{\circ} \mathrm{C}$, mobile phase: methanol: water $80: 20(v / v)$, and flow rate $1.0 \mathrm{~mL} / \mathrm{min}$. The sample was filtered through a $0.45 \mu \mathrm{m}$ filter, and the injection volume was $20 \mu \mathrm{L}$ and the detection wavelength was $206 \mathrm{~nm}$. Experimental results of accuracy of bifenthrin analysis method were shown in Table S3.

\section{Conclusions}

In this study, a novel carboxylesterase derived from Geobacillus uzenensis 23175 was cloned and named Est ${ }_{741}$, and its expression and purification were achieved in E. coli and P. pastoris. We further mutated it and immobilized the carboxylesterase on epoxy resin $1 x-105 s$, and finally obtained the immobilized enzyme $1 \mathrm{x}$-Est $\mathrm{M}_{\mathrm{M} 160 \mathrm{~K}}$. The $1 \mathrm{x}$-Est $\mathrm{M}_{\mathrm{M} 160 \mathrm{~K}}$ biocatalyst was first used for the hydrolysis of malathion and bifenthrin in wastewater, and a packed bed column reactor has been designed, hoping to make better use of the immobilized enzyme lx-Est ${ }_{\mathrm{M} 160 \mathrm{~K}}$ in industry. Due to its high biocatalytic and environmentally friendly properties, $1 \mathrm{x}$-Est ${ }_{\mathrm{M} 160 \mathrm{~K}}$ could potentially be used to treat pesticide pollution in agricultural production.

Supplementary Materials: The following are available online at http://www.mdpi.com/2073-4344/10/5/518/s1, Figure S1: Transformation and screening of recombinant P. pastoris. Figure S2: Expression and SDS-PAGE analysis of Est ${ }_{\mathrm{M} 160 \mathrm{~K}}$ in E. coli and Pichia pastoris. Figure S3: SEM of the surface of epoxy resin lx-105s before and after immobilization of Est ${ }_{\mathrm{M} 160 \mathrm{~K}}$. Figure S4: Degradation of malathion by immobilized lx-Est ${ }_{\mathrm{M} 160 \mathrm{~K}}$ and packed-bed bioreactor for biodegradation of bifenthrin. Figure S5: The standard curve of malathion. Figure S6: Detection wavelength of bifenthrin, physical picture of degradation reactor and HPLC detection results. Table S1: Substrate specificity of lx-Est $160 \mathrm{~K}$. Table S2: Sequences of primers used in this study. Table S3: Experimental results of accuracy of bifenthrin analysis method.

Author Contributions: X.Y., D.W., and W.W. conceived and designed the experiments; X.Y. and X.T. performed the experiments; F.D. and X.Y. analyzed the data; X.Y. wrote the paper; L.L. and W.W. contributed investigation/materials/analysis tools; X.Y. and W.W. revised the paper. All authors have read and agreed to the published version of the manuscript

Funding: This study was funded by the National Natural Science Foundation of China (No. C31570795), the Shanghai outstanding technical leaders plan 19XD1431800, 19XD1431900, the National Natural Science Foundation of China (Grant No. 81830052, 81530053), and Shanghai Key Laboratory of Molecular Imaging (18DZ2260400).

Conflicts of Interest: The authors declare no conflict of interest.

\section{Abbreviations}

$\begin{array}{ll}\text { AOX } & \text { alcohol oxidase } \\ \text { CTAB } & \text { cetyltrimethylammonium bromide } \\ \text { EDTA } & \text { ethylene diamine tetraacetic acid } \\ \text { PBR } & \text { packed bed reactor } \\ \text { SDS } & \text { sodium dodecyl sulfate } \\ \text { SDS-PAGE } & \text { sodium dodecyl sulfate polyacrylamide gel electrophoresis } \\ \text { SEM } & \text { scanning electron microscopy } \\ \text { UV-Vis } & \text { ultraviolet and visible spectrophotometry }\end{array}$




\section{References}

1. Cai, X.; Wang, W.; Lin, L.; He, D.; Huang, G.; Shen, Y.; Wei, W.; Wei, D. Autotransporter domain-dependent enzymatic analysis of a novel extremely thermostable carboxylesterase with high biodegradability towards pyrethroid pesticides. Sci. Rep. 2017, 7, 3461. [CrossRef]

2. Le, L.T.H.L.; Yoo, W.; Jeon, S.; Kim, K.K.; Kim, T.D. Characterization and Immobilization of a Novel SGNH Family Esterase (LaSGNH1) from Lactobacillus acidophilus NCFM. Int. J. Mol. Sci. 2020, 21, 91. [CrossRef] [PubMed]

3. Bhatt, P.; Huang, Y.; Zhan, H.; Chen, S. Insight into microbial applications for the biodegradation of pyrethroid insecticides. Front. Microbiol. 2019, 10, 1778. [CrossRef] [PubMed]

4. Liu, W.; Li, M.; Yan, Y. Heterologous expression and characterization of a new lipase from Pseudomonas fluorescens Pf0-1 and used for biodiesel production. Sci. Rep. 2017, 7, 15711. [CrossRef]

5. Kambiranda, D.M.; Asraful-Islam, S.M.; Cho, K.M.; Math, R.K.; Lee, Y.H.; Kim, H.; Yun, H.D. Expression of esterase gene in yeast for organophosphates biodegradation. Pestic. Biochem. Physiol. 2009, 94, 15-20. [CrossRef]

6. Zuo, Z.; Gong, T.; Che, Y.; Liu, R.; Xu, P.; Jiang, H.; Qiao, C.; Song, C.; Yang, C. Engineering Pseudomonas putida KT2440 for simultaneous degradation of organophosphates and pyrethroids and its application in bioremediation of soil. Biodegradation 2015, 26, 223-233. [CrossRef]

7. Gudiukaite, R.; Sadauskas, M.; Gegeckas, A.; Malunavicius, V.; Citavicius, D. Construction of a novel lipolytic fusion biocatalyst GDEst-lip for industrial application. J. Ind. Microbiol. Biotechnol. 2017, 44, 799-815. [CrossRef] [PubMed]

8. O'Neill, M.; Beecher, D.; Mangan, D.; Rowan, A.S.; Monte, A.; Sroka, S.; Modregger, J.; Hundle, B.; Moody, T.S. A novel lipase enzyme panel exhibiting superior activity and selectivity over lipase B from Candida antarctica for the kinetic resolution of secondary alcohols. Tetrahedron Asymmetry 2012, 23, 583-586. [CrossRef]

9. Kandhari, N.; Sinha, S. Complex network analysis of thermostable mutants of Bacillus subtilis Lipase A. Appl. Netw. Sci. 2017, 2, 18. [CrossRef]

10. Mohammadi, M.; Sepehrizadeh, Z.; Ebrahim-Habibi, A.; Shahverdi, A.R.; Faramarzi, M.A.; Setayesh, N. Enhancing activity and thermostability of lipase A from Serratia marcescens by site-directed mutagenesis. Enzyme. Microb. Technol. 2016, 93-94, 18-28. [CrossRef]

11. Heidari, R.; Devonshire, A.L.; Campbell, B.E.; Dorrian, S.J.; Oakeshott, J.G.; Russell, R.J. Hydrolysis of pyrethroids by carboxylesterases from Lucilia cuprina and Drosophila melanogaster with active sites modified by in vitro mutagenesis. Insect Biochem. Mol. Biol. 2005, 35, 597-609. [CrossRef] [PubMed]

12. Angkawidjaja, C.; Koga, Y.; Takano, K. Structure and stability of a thermostable carboxylesterase from the thermoacidophilic archaeon Sulfolobus tokodai. FEBS J. 2012, 279, 3071-3084. [CrossRef]

13. Chen, B.; Hu, J.; Miller, E.M.; Xie, W.; Cai, M.; Gross, R.A. Candida antarctica lipase B chemically immobilized on epoxy-activated micro- and nanobeads: Catalysts for polyester synthesis. Biomacromolecules 2008, 9, 463-471. [CrossRef] [PubMed]

14. Mihailović, M.; Stojanović, M.; Banjanac, K.; Carević, M.; Prlainović, N.; Milosavić, N.; Bezbradica, D. Immobilization of lipase on epoxy-activated Purolite @A109 and its post-immobilization stabilization. Process Biochem. 2014, 49, 637-646. [CrossRef]

15. Singh, B.; Kaur, J.; Singh, K. Biodegradation of malathion by Brevibacillus sp. strain KB2 and Bacillus cereus strain PU. World J. Microb. Biotechnol. 2012, 28, 1133-1141. [CrossRef]

16. Tazdaiit, D.; Abdi, N.; Lounici,H.; Grib,H.; Mameri, N.; Pauss, A. Biodegradation of malathion with indigenous acclimated activated sludge in batch mode and in continuous-flow packed-bed reactor. Bioremediation J. 2013, 17, 294-304. [CrossRef]

17. Salum, T.F.C.; Villeneuve, P.; Barea, B.; Yamamoto, C.I.; Côcco, L.C.; Mitchell, D.A.; Krieger, N. Synthesis of biodiesel in column fixed-bed bioreactor using the fermented solid produced by Burkholderia cepacia LTEB11. Process Biochem. 2010, 45, 1348-1354. [CrossRef]

18. Nguyen, L.N.; Hai, F.I.; Dosseto, A. Continuous adsorption and biotransformation of micropollutants by granular activated carbon-bound laccase in a packed-bed enzyme reactor. Bioresour. Technol. 2016, 210, 108-116. [CrossRef] 
19. Karpushova, A.; Brümmer, F.; Barth, S.; Lange, S.; Schmid, R.D. Cloning, recombinant expression and biochemical characterisation of novel esterases from Bacillus sp. associated with the marine sponge Aplysina aerophoba. Appl. Microbiol. Biotechnol. 2005, 67, 59-69. [CrossRef]

20. Chiş, L.; Hriscu, M.; Bica, A.; Toşa, M.; Nagy, G.; Róna, G.; G Vértessy, B.; Dan, I.F. Molecular cloning and characterization of a thermostable esterase/lipase produced by a novel Anoxybacillus flavithermus strain. J. Gen. Appl. Microbiol. 2013, 59, 119. [CrossRef]

21. Unrean, P. Pathway analysis of Pichia pastoris to elucidate methanol metabolism and its regulation for production of recombinant proteins. Biotechnol. Progr. 2014, 30, 28-37. [CrossRef] [PubMed]

22. Madan, B.; Mishra, P. Directed evolution of Bacillus licheniformis lipase for improvement of thermostability. Biochem. Eng. J. 2014, 91, 276-282. [CrossRef]

23. Kumar, R.; Singh, R.; Kaur, J. Characterization and molecular modelling of an engineered organic solvent tolerant, thermostable lipase with enhanced enzyme activity. J. Mol. Catal. B Enzym. 2013, 97, $243-251$. [CrossRef]

24. Li, C.; Tan, T.; Zhang, H.; Feng, W. Analysis of the conformational stability and activity of Candida antarctica lipase B in organic solvents insight from molecular dynamics and quantum mechanics/simulations. J. Biol. Chem. 2010, 285, 28434-28441. [CrossRef] [PubMed]

25. Souza, S.P.D.; Almeida, R.A.D.; Garcia, G.G.; Leão, R.A.; Bassut, J.; Souza, R.O.D.; Itabaiana, I., Jr. Immobilization of lipase B from Candida antarctica on epoxy-functionalized silica: Characterization and improving biocatalytic parameters. J. Chem. Technol. Biotechnol. 2018, 93, 105-111. [CrossRef]

26. Li, X.; Li, D.; Wang, W.; Durrani, R.; Bo, Y.; Wang, Y. Immobilization of SMG1-F278N lipase onto a novel epoxy resin: Characterization and its application in synthesis of partial glycerides. J. Mol. Catal. B Enzym. 2016, 133, 154-160. [CrossRef]

27. Ren, Y.; He, B.; Yan, F.; Wang, H.; Cheng, Y.; Lin, L.; Feng, Y.; Li, J. Continuous biodiesel production in a fixed bed reactor packed with anion-exchange resin as heterogeneous catalyst. Bioresour. Technol. 2011, 113, 19-22. [CrossRef]

28. Mateo, C.; Grazu, V.; Palomo, J.M.; Lopezgallego, F.; Fernandezlafuente, R.; Guisan, J.M. Immobilization of enzymes on heterofunctional epoxy supports. Nat. Protoc. 2007, 2, 1022-1033. [CrossRef]

29. Palomo, J.M.; Muñoz, G.; Gloria, F.L. Modulation of Mucor miehei lipase properties via directed immobilization on different hetero-functional epoxy resins: Hydrolytic resolution of $(R, S)$-2-butyroyl2-phenylacetic acid. J. Mol. Catal. B Enzym. 2003, 21, 201-210. [CrossRef]

30. Rodrigues, J.; Canet, A.; Rivera, I. Biodiesel production from crude Jatropha oil catalyzed by non-commercial immobilized heterologous Rhizopus oryzae and Carica papaya lipases. Bioresour. Technol. 2016, 213, 88-95. [CrossRef]

31. Goda, S.K.; Elsayed, I.E.; Khodair, T.A.; El-Sayed, W.; Mohamed, M.E. Screening for and isolation and identification of malathion-degrading bacteria: Cloning and sequencing a gene that potentially encodes the malathion-degrading enzyme, carboxylestrase in soil bacteria. Biodegradation 2010, 21, 903-913. [CrossRef]

32. Xie, Z.; Xu, B.; Ding, J.; Liu, L.; Zhang, X.; Li, J.; Huang, Z. Heterologous expression and characterization of a malathion-hydrolyzing carboxylesterase from a thermophilic bacterium, Alicyclobacillus tengchongensis. Biotechnol. Lett. 2013, 35, 1283-1289. [CrossRef]

33. Schofield, D.A.; Dinovo, A.A. Generation of a mutagenized organophosphorus hydrolase for the biodegradation of the organophosphate pesticides malathion and demeton-S. J. Appl. Microbiol. 2010, 109, 548-557. [CrossRef] [PubMed]

34. Xue, Y.P.; Jiang, T.; Liu, X.; Zheng, Y.G. Efficient production of S-(+)-2-chlorophenylglycine by immobilized penicillin $\mathrm{G}$ acylase in a recirculating packed bed reactor. Biochem. Eng. J. 2013, 74, 88-94. [CrossRef]

35. Feng, Y.; Zhang, A.; Li, J.; He, B. A continuous process for biodiesel production in a fixed bed reactor packed with cation-exchange resin as heterogeneous catalyst. Bioresour. Technol. 2012, 113, 19-22. [CrossRef] [PubMed]

36. Xiao, Y.; Basu, A.; Kashyap, V.; Roberts, D. Experimental and numerical analysis of biological regeneration of perchlorate laden ion-exchange resins in batch reactors. Environ. Eng. Sci. 2010, 27, 75-83. [CrossRef]

37. Priji, P.; Unni, K.N.; Sajith, S.; Binod, P.; Benjamin, S. Production, optimization, and partial purification of lipase from Pseudomonas sp. strain BUP6, a novel rumen bacterium characterized from Malabari goat. Biotechnol. Appl. Biochem. 2015, 62, 71-78. [CrossRef] 
38. Babaki, M.; Yousefi, M.; Habibi, Z.; Brask, J.; Mohammadi, M. Preparation of highly reusable biocatalysts by immobilization of lipases on epoxy-functionalized silica for production of biodiesel from canola oil. Biochem. Eng. J. 2015, 101, 23-31. [CrossRef]

39. Jeganathan, J.; Nakhla, G.; Bassi, A. Hydrolytic pretreatment of oily wastewater by immobilized lipase. J. Hazard. Mater. 2007, 145, 127-135. [CrossRef]

40. Harshit, D.; Charmy, K.; Nrupesh, P. Organophosphorus pesticides determination by novel HPLC and spectrophotometric method. Food Chem. 2017, 230, 448-453. [CrossRef]

41. Peng, G.; He, Q.; Lu, Y.; Mmereki, D.; Zhong, Z. Determination of organophosphorus pesticides and their major degradation product residues in food samples by HPLC-UV. Environ. Sci. Pollut. Res. Int. 2016, 23, 19409-19416. [CrossRef] [PubMed]

42. Bouri, M.; Salghi, R.; Bazzi, L.; Zarrouk, A.; Rios, A.; Zougagh, M. Pesticide residue levels in green beans cultivated in Souss Masa valley (Morocco) after multiple applications of bifenthrin and $\lambda$-cyhalothrin. Bull. Environ. Contam. Toxicol. 2012, 89, 638-643. [CrossRef] [PubMed]

(C) 2020 by the authors. Licensee MDPI, Basel, Switzerland. This article is an open access article distributed under the terms and conditions of the Creative Commons Attribution (CC BY) license (http://creativecommons.org/licenses/by/4.0/). 